\title{
Identifikasi Kerusakan dan Sistem Pengumpulan Data Konservasi Benda Cagar Budaya Bawah Air
}

\author{
Oleh : \\ Ari Swastikawati, S.Si \\ Balai Konservasi Peninggalan Borobudur
}

\section{Indentifikasi Kerusakan BCB Bawah Air}

Identifikasi berasal dari kata identity yang artinya ciri-ciri dan menjadi "identification" artinya pengenalan. Sehingga yang dimaksud dengan identifikasi kerusakan bcb bawah adalah suatu usaha untuk mengetahui atau mengenal ciri-ciri, tanda-tanda, atau sifat-sifat spesifik kerusakan bcb bawah air.

Pada dasarnya semua benda yang ada di alam ini, termasuk tinggalan bawah air akan mengalami proses interaksi dengan lingkungan. Interaksi tersebut merupakan sebuah proses yang tidak dapat dihindarkan, sebab semua benda akan mengalami proses penuaan secara alamiah (natural ageing) yang pada giliranya sifat-sifat alami bahan yang digunakan akan mengalami proses degradasi atau menurun kualitasnya. Perubahan atau degradasi bahan tinggalan arkeologi bawah air dapat dikelompokkan menjadi dua yaitu kerusakan dan pelapukan.

(a) Kerusakan adalah suatu proses perubahan yang terjadi pada bahan tanpa dikuti oleh perubahan unsur-unsurnya, contoh pecah dan retak.

(b) Pelapukan adalah suatu proses perubahan baik sifat fisik (desintegrasi) maupun kimiawinya (dekomposisi), yang diikuti dengan gejala kerapuhan, korosi atau pembusukan.

Berdasarkan faktor penyebabnya, proses degradasi tinggalan bawah air dapat dikelompokkan menjadi dua faktor, yaitu faktor internal dan faktor eksternal:

(a) Faktor internal

Faktor internal terkait dengan sifat-sifat alami tinggalan arkeologi bawah air yang dapat terbuat bahan organik atau anorganik. $\mathrm{Hal}$ ini akan menentukan ketahanan benda tersebut dalam interaksinya dengan faktor lingkungan.

(b) Faktor eksternal

Faktor eksternal adalah kondisi lingkungan dimana tinggalan arkeologi bawah air berada, baik selama masih berada di dalam air laut maupun sesudah diangkat.

Berdasarkan prosesnya, degradasi yang terjadi pada tinggalan bawah air dapat dikelompokkan menjadi empat yaitu, proses kerusakan secara mekanis, pelapukan secara fisis, pelapukan secara khemis dan pelapukan secara biotis.

(a) Kerusakan mekanis

Kerusakan mekanis yang terjadi pada tinggalan arkeologi bawah air pada umumnya terjadi sebagai akibat dari musibah tenggelamnya kapal. Sifat kerusakan yang terjadi lebih banyak karena gaya yang bersifat dinamis, sehingga ciriciri kerusakan yang terjadi kebanyakan berupa retakan, pecahan, atau kehancuran. Hal itu tentu saja akan sangat tergantung dari kondisi dan posisi dimana benda tersebut, ketika musibah tersebut terjadi.

(b) Pelapukan secara fisis Dalam keadaan dimana tinggalan bawah air tersebut masih berada di bawah air, maka pelapukan secara fisis dapat dikatakan tidak terjadi. Namun demikian apabila tinggalan arkeologi bawah air tersebut sudah diangkat, maka peranan faktor lingkungan mikro harus dipertimbangkan secara cermat. Faktor utama yang berperan adalah fluktuasi suhu dan kelembapan. Ciri-ciri atau tandatanda kerusakan yang terjadi adalah adanya retakan mikro maupun makro.

(c) Pelapukan secara khemis Agensia utama proses terjadinya pelapukan secara kimiawi adalah air, dalam hal ini adalah air laut khususnya sewaktu tinggalan arkeologi bawah air tersebut masih berada di dalam air laut. Air laut yang mengandung garam-garam terlarut tidak hanya terakumulasi pada permukaan benda tetapi juga meresap ke dalam pori-pori. Selama kondisinya masih di dalam laut dapat dikatakan relatif stabil, tetapi setelah diangkat dimana kondisi lingkungan mikro berubah drastis. Endapan garam-garam terlarut akan mengering dan mengeras. Garam-garam tersebut umumnya masih aktif sehingga akan menimbulkan korosi sebagian mineral bahan penyusun tinggalan bawah air. Ciri-ciri kerusakan akibat pelapukan secara kimiawi adalah adanya endapan garam atau kerak akibat proses korosi. Jenis garam yang paling dominan adalah karbonat $\left(\mathrm{CO}_{3}{ }^{2}\right)$, dan klorida $\left(\mathrm{Cl}^{2}\right)$ dll. Dan yang jarang atau jumlahnya paling sedikit adalah sulfat $\left(\mathrm{SO}_{4}{ }^{2}\right)$, sulfat 
biasanya ditemukan pada artefak berbahan logam khususnya tembaga.

(d) Pelapukan secara biotis Pelapukan secara biotis pada tinggalan arkeologi bawah air terutama disebabkan oleh adanya serangan beberapa jenis binatang karang, moluska dan crustacea. Pada umunya binatang karang tumbuh dipermukaan benda baik benda yang terbuat dari bahan organik maupun anorganik. Keberadaan cacing laut pada umumnya menimbulkan kerusakan yang sangat berarti yaitu dalam bentuk lubang-lubang pada kayu. Selain lubang-lubang tersebut pelapukan biotis pada kayu juga menyebabkan kayu bersifat lebih porus dan kualitasnya menurun.

\section{Sistem Pengumpulan Data Konservasi BCB Bawah Air}

Ditinjau dari istilah sistem berasal dari kata "system" berarti susunan, tata cara, atau cara sedangkan kata "data" berarti, fakta atau bahan-bahan keterangan/ informasi. Konservasi berasal dari bahasa Inggris "conservation" yang berarti pemeliharaan, pengawetan atau dapat pula diartikan perawatan. Oleh karena itu yang dimaksud dengan sistem pengumpulan data konservasi benda cagar budaya bawah air adalah cara atau tata cara pengumpulan data untuk kepentingan pemeliharaan atau pengawetan benda cagar budaya bawah air. Pada intinya data atau informasi yang dikumpulkan meliputi identitas artefak, kondisi artefak, proses konservasi dan hasil konservasi. Data tentang kondisi koleksi yang detail dan selengkap mungkin diharapkan akan sangat membantu pelaksanaan konservasi koleksi dan membantu mengetahui perubahan-perubahan yang terjadi pada koleksi.

Data atau informasi dalam konservasi umumnya dalam dua bentuk yaitu data verbal dalam bentuk tulisan dan data visual dalam bentuk gambar atau foto koleksi. Data verbal secara garis besar berisi asal temuan, jenis koleksi, jenis bahan dan kondisi koleksi menjadi bahan pertimbangan dilakukanya konservasi. Hasil pendataan tersebut dikumpulkan dalam form atau kartu perawatan koleksi. Pengambilan data sebaiknya dilakukan sebelum, selama dan sesudah tindakan konservasi. Data koleksi bawah air sebelum konservasi dilaksanakan akan sangat berguna untuk menentukan metode dan teknik konservasi, serta bahan konservasi yang akan digunakan. Sebagai contoh koleksi temuan bawah air berbahan keramik dalam kondisi pecah maka diperlukan tindakan pengeleman, contoh lain koleksi temuan berupa tembikar yang permukaanya dipenuhi dengan endapan garam maka diperlukan tindakan pembersihan endapan/ kerak garam dengan metode mekanik, fisik atau khemis. Data koleksi setelah tindakan konservasi sangat diperlukan untuk mengevaluasi hasil konservasi atau jika terjadi kejadian tertentu yang menyebabkan tindakan konservasi harus diulang. Sebagai contoh koleksi keramik jenis stone-ware yang sudah direstorasi menggunakan adhesiv atau lem jenis epoksi resin maka jika keramik tersebut jatuh dan pecah pada bagian lain maka agar hasil restorasi ulang baik maka sebaiknya menggunakan jenis adhesiv yang sama. Contoh lain jika hasil pengeleman keramik lepas setelah dua tahun maka dengan melihat kartu perwatan dapat diketahui jenis lem misal acryloid B 72 (merk dagang di pasaran paraloid B-72) sehingga dapat segera ditentukan jenis pelarut yang dapat digunakan untuk menghilangkan lem lama yaitu toluene, setelah bersih baru dioleskan lem yang baru.

Point-point apa saja yang seharusnya ada dalam kartu perawatan bcb bawah air:

A. Sebelum pelaksanaan konservasi perlu diketahui terutama asal, jenis bahan penyusun, jenis kerusakan dan pelapukan serta langkah-langkah yang perlu diambil, antara lain:

1. Nomor kode perawatan bcb bawah air / koleksi

Berisi nomor urut perawatan, bulan dan tahun pelaksanaan konservasi, contoh perawatan koleksi 0012/04/2008 berarti nomor urut perwatan 12, dilaksanakan pada bulan 4 (April) tahun 2008.

2. Nama artefak

3. Jenis bcb:

4. Nomor koleksi

Nomor koleksi dapat diisi dengan nomor registrasi atau nomor inventarisasi yang sudah diberikan sebelumnya.

5. Asal/tempat ditemukan Dari mana asal bcb sangat penting untuk mengetahui faktor ektrinsik, dalam hal ini lingkungan yang berpengaruh terhadap $\mathrm{k}$ e r u s a a n d a $\mathrm{n}$ pelapukannya. Jenis perairan yang merendamnya, karena air laut dan air tawar (sungai atau danau) memiliki salinitas yang berbeda.

6. Jenis bahan

Jenis bahan koleksi merupakan faktor intrinsik yang dapat berpengaruh terhadap jenis kerusakan atau pelapukan yang terjadi 
pada benda cagar budaya bawah air. Jenis bahan secara umum dapat dibagi menjadi bahan organik atau anorganik.

(a) Bahan organik adalah bahan yang berasal atau dihasilkan oleh organisme misalnya kayu, kulit, tulang, tekstil;

(b) Bahan anorganik adalah bahan yang tidak berasal atau tidak dihasilkan oleh organisme, contoh keramik, logam, bata dan batu.

Keramik sendiri bisa dibagi lagi menjadi: stone-ware, porselin dan tembikar. Keramik banyak ditemukan dalam bentuk peralatan rumah tangga, seperti piring dan mangkok. Jenis logam dapat berupa perunggu, kuningan, besi, perak atau emas. Logam banyak ditemukan dalam bentuk uang kepeng, arca, mahkota atau perhiasan.

Perunggu merupakan "alloy" atau logam paduan antara tembaga $(\mathrm{Cu})$ dan timah putih $(\mathrm{Sn})$ $\mathrm{dalam}$ bermacam-macam perbandingan, ditambah dengan logam-logam lain seperti zeng ( $\mathrm{Zn})$, timah hitam $(\mathrm{Pb})$ dan besi $(\mathrm{Fe})$ dalam jumlah kecil sebagai logam penyerta. Komposisi umum tembaga dan timah putih dalam perunggu berkisar antara 75\%-85\% Cu dan 15\% - 25\% timah. Perunggu dengan komposisi $87 \%$ Cu dan $13 \%$ Sn merupakan logam campuan yang keras dan kuat.

Kuningan merupakan "alloy" atau logam campuran antara tembaga $(\mathrm{Cu})$ dengan seng $(\mathrm{Zn})$ serta logam-logam lain seperti timah putih ( $\mathrm{Sn})$, timah hitam $(\mathrm{Pb})$, besi (Fe) dalam jumlah kecil sebagai logam penyerta. Kuningan dengan komposisi $61 \%$ tembaga dan 39\% seng merupakan logam campuran yang kenyal.

$$
\text { Jenis batuan dapat }
$$

berupa batu andesit, bata, marmer atau manik-manik. Batu andesit dapat ditemukan sebagai arca ataupun sebagai pemberat kapal. Jenis batu marmer ditemukan sebagai batu nisan. Sedangkan manikmanik biasanya berupa hiasan atau sebagai bekal kubur.

\section{Diagnosa kerusakan}

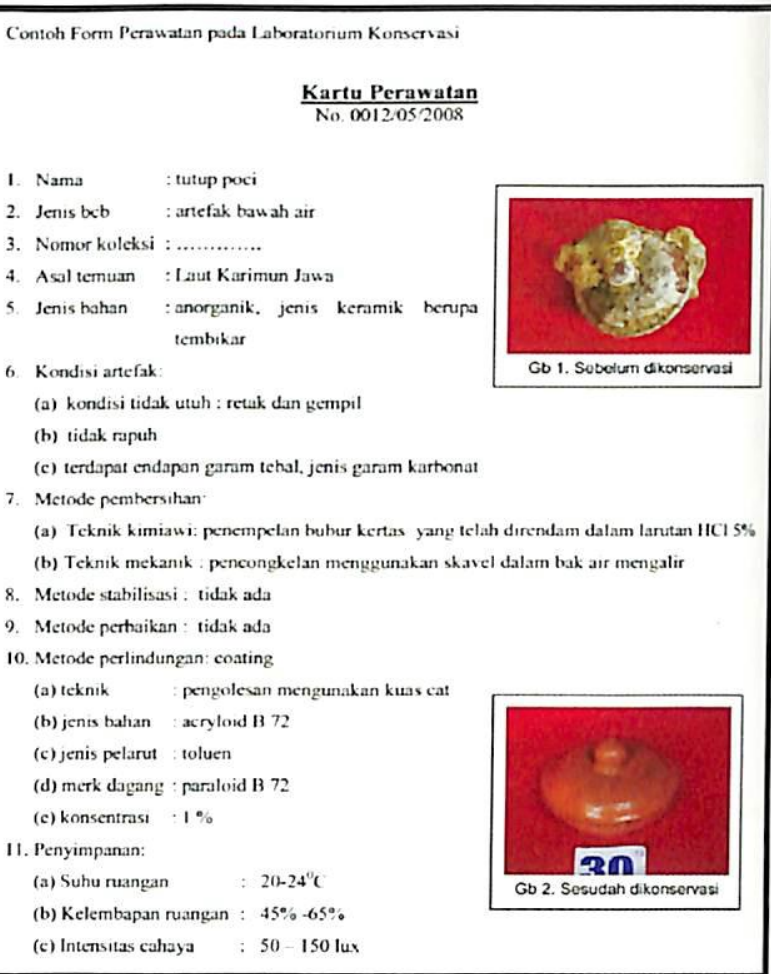

2. Kondisi artefak

(a) Kondisi fisik artefak tersebut apakah utuh, atau tidak utuh. Tidak utuh contohnya pecah, gempil, retak, berlubang ataupun fragmen yang ditemukan tidak lengkap;

(b) Tingkat kerapuhan: tidak rapuh dan rapuh (terutama untuk artefak yang berbahan organik);

(c) Ada tidaknya endapan garam ataupun kerak akibat proses korosi. Jika ada lakukan uji kualitatif untuk menentukan jenis garam atau kerak tersebut;

(d) Ada tidaknya lapisan patina khususnya artefak berbahan perunggu dan kuningan.

B.Selama tindakan konservasi meliputi metode, teknik serta bahan yang digunakan:

8. Motode pembersihan endapan garam atau kerak

Teknik yang digunakan:

(a) $\mathrm{Mekanik} \mathrm{dengan}$ mengunakan sikat gigi, skavel, ampelas dan palu kecil;

(b) Fisik dengan cara pemanasan udara kering (oven) atau perebusan. Teknik ini hanya digunakan untuk artefak keramik atau artefak lain yang sifat bahannya tahan terhadap panas dengan suhu 100 1500C selama 1-1,5 jam;

(c) Kimia, teknik pembersihan secara kimiawi dapat dilakukan dengan perendaman artefak dalam larutan tertentu atau penempelan bubur kertas (biasanya kertas tissue) yang sudah direndam dalam larutan tertentu pada permukaan artefak. Cantumkan jenis bahan dan konsentrasi yang digunakan serta waktu perendaman atau waktu kontak bubur kertas. Khusus untuk artefak perunggu dapat dilakukan dengan teknik reduksi yaitu elektrolisa dan elektrokimia, imobilisasi dengan perak oksida 
(Ag2O).

9. Metode stabilisasi, bertujuan untuk menstabilakan artefak yang berbahan logam seperti perunggu dan kuningan. Teknik yang dilakukan dalam stabilisasi biasanya dilakukan dengan cara perendaman. Bahan kimia yang digunakan yaitu: BTA 3\% dan kalium bikromat $5 \%$.

10. Metode perbaikan, berkaitan untuk penanganan artefak yang pecah, retak atau rapuh Teknik yang digunakan:

(a) Penyambungan fragmen yang pecah meliputi data jenis lem/adhesiv dan pelarut yang digunakan, berapa vikositas atau kekentalannya

(b) Injeksi retakan meliputi data jenis lem/adhesiv dan pelarut yang digunakan, berapa vikositas atau kekentalannya;

(c) Konsolidasi untuk artefak yang rapuh meliputi data jenis konsolidan/adhesiv dan pelarut yang digunakan, $b$ e $r$ a $p$ a vikositas/kekentalan ataupun konsentrasinya.

11. Metode perlindungan artefak dengan pelapisan (coating) atau apikasi bahan insektisida atau fungisida khususnya untuk artefak yang berbahan organik. Data jenis bahan kimia, jenis pelarut, merk dagang serta konsentrasi yang digunakan.

Teknik yang digunakan

(a) P e r e nd a man a t a u pencelupan dalam larutan kimia

(b) Pengolesan mengunakan kuas cat.

C. Setelah tindakan konservasi meliputi :

12. Saran penyimpanan terutama pengendalian lingkungan artefak meliputi:

(a) Suhu ruangan : (20-240C)

(b) Kelembapan ruangan: (45\%-65\%)

(c) Intensitas cahaya : $(50-150$ lux)

Sertakan foto sebelum dan sesudah artefak dikonservasi, disertai skala.

Berikut beberapa form pekerjaan konservasi $\mathrm{BCB}$ bawah air :

Daftar Pustaka

Hamilton, D.L. 1999. Methods of Conserving Archeological Material from Underwater Site. dlhamilton@tamu.edu.

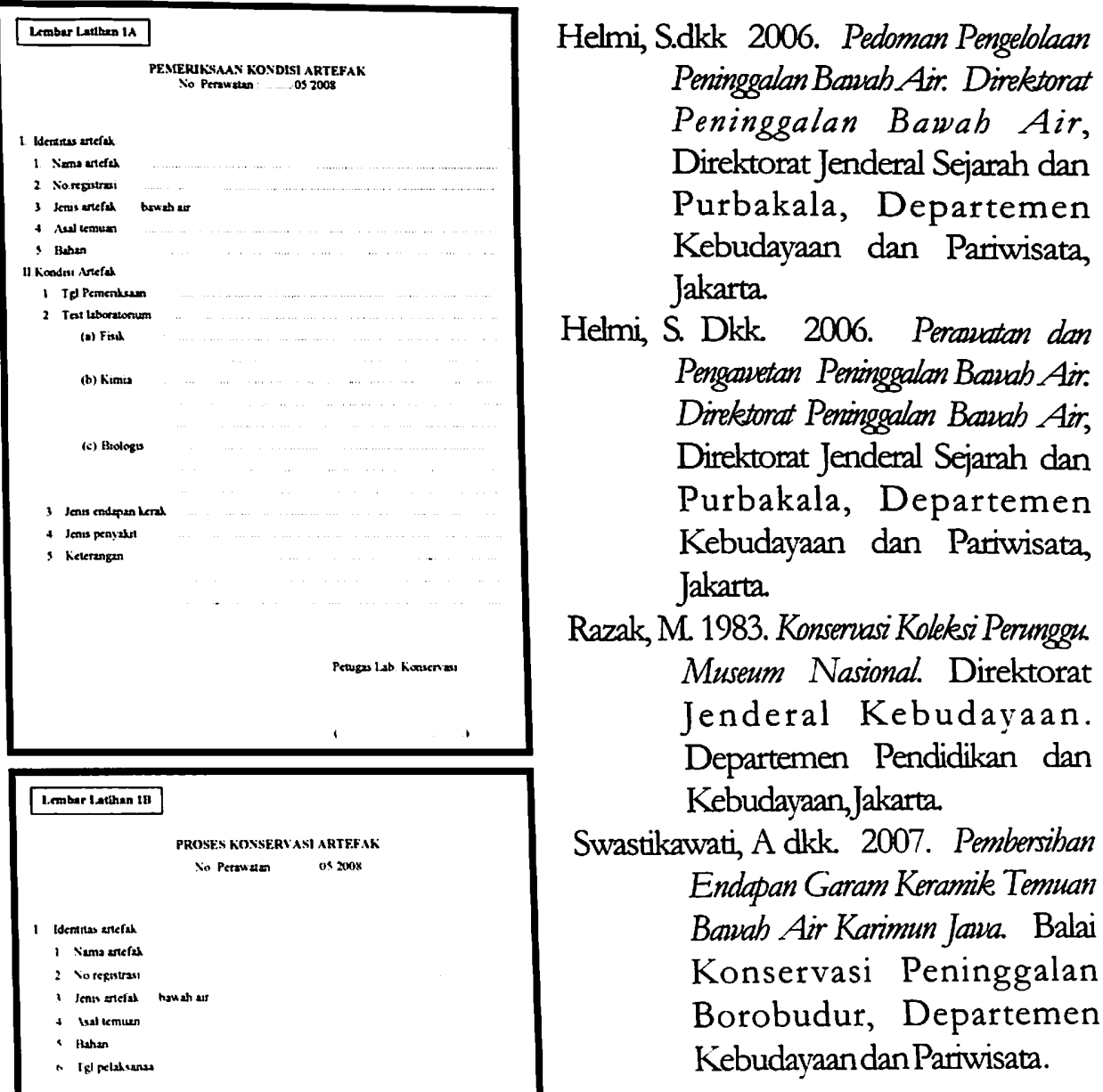

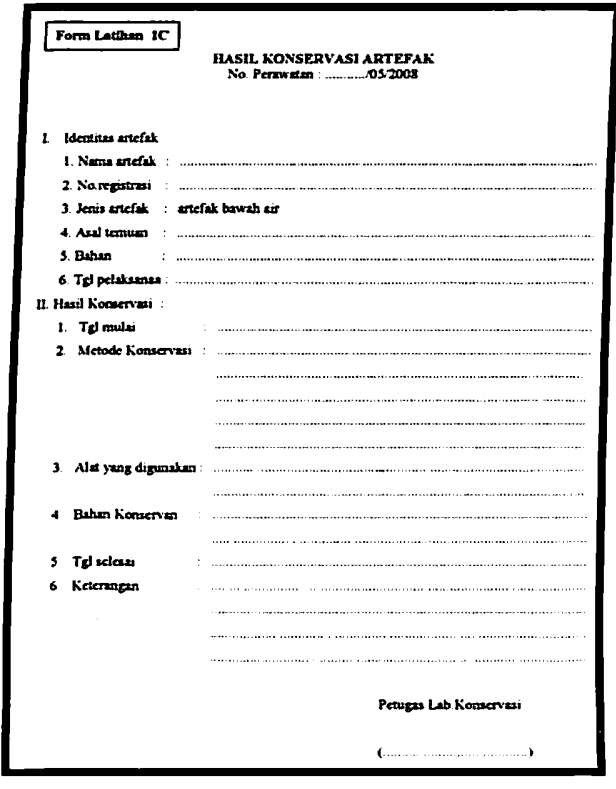

Helmi, S.dkk 2006. Pedoman Pengelolaan Peninggalan Banvah Air. Direktorat Peninggalan Bawab Air, Direktorat Jenderal Sejarah dan urbakala, Departemen Kebudayaan dan Pariwisata, Direktorat Peningralan Basuab Air, Direktorat Jenderal Sejarah dan Purbakala, Departemen Kebudayaan dan Pariwisata,

Museum Nasional. Direktorat enderal Kebudayaan. Departemen Pendidikan dan 